\title{
PATHOGENETIC ASPECTS OF INFERTILITY IN WOMEN OF REPRODUCTIVE AGE WITH OVARIAN VARICOCELE
}

\author{
Astakhova O. V. \\ Vinnytsia National Medical Pirogov memorial University, Ukraine, \\ ORCID ID: https://orcid.org/0000-0002-6073-0473
}

DOI: https://doi.org/10.31435/rsglobal_ws/30062020/7106

\section{ARTICLE INFO \\ Received: 14 April 2020 \\ Accepted: 10 June 2020 \\ Published: 30 June 2020}

\section{KEYWORDS}

ovarian varicocele, infertility,

varicose veins of the pelvis, phlebostasis, ovarian vein.

\begin{abstract}
To date, the problem of reduced fertility is quite relevant. At the same time, it should be noted that the effectiveness of infertility treatment, even with the use of the latest techniques, tools and drugs does not exceed $35-40 \%$. This can be explained by insufficient study of a number of causes that lead to impaired fertility.

One of these little-known and poorly studied factors is pelvic venous plethora, in particular varicose veins of the ovaries. While anatomically similar disease in men - varicocele - is given great importance, in women, even the very existence of this pathology is controversial among some authors.

All studies were conducted in compliance with the basic bioethical norms and requirements of the Declaration of Helsinki. 117 women of reproductive age (21 - 42 years) with infertility of functional genesis were examined.

According to the results of the analysis, the clinical and anamnestic features of women with infertility and ovaric varicocele are increased proportion of patients with intellectual differentiation and psychoemotional and physical stress, high frequency of infectious diseases with acyclic uterine bleeding, dysmenorrhea and premenstrual. Changes in the anatomical and functional state of the pelvic organs and venous system in women with infertility and ovarian varicocele have been established. It was found that the hormonal profile of women with infertility and ovarian varicocele is characterized by a decrease in estradiol and progesterone. A pathogenetically sound algorithm for the diagnosis and treatment of women with infertility and ovarian varicocele has been developed, which is based on clinical data and the results of instrumental methods of examination.
\end{abstract}

Citation: Astakhova O. V. (2020) Pathogenetic Aspects of Infertility in Women of Reproductive Age with Ovarian Varicocele. World Science. 6(58), Vol.2. doi: 10.31435/rsglobal_ws/30062020/7106

Copyright: (C) 2020 Astakhova O. V. This is an open-access article distributed under the terms of the Creative Commons Attribution License (CC BY). The use, distribution or reproduction in other forums is permitted, provided the original author(s) or licensor are credited and that the original publication in this journal is cited, in accordance with accepted academic practice. No use, distribution or reproduction is permitted which does not comply with these terms.

Introduction. The problem of reproductive health in Ukraine has become of great importance in the last decades. The socio-economic crisis has led to a rapid rate of depopulation - a decrease in population. In terms of fertility rate, Ukraine is among the 8 countries with the lowest childbearing activity $[6,8]$.

The incidence of infertility in the world ranges from 10-15 to $18-29 \%$ and there is a steady tendency to its rapid increase, which makes this pathology a national problem. The demographic consequences of infertility include a general decline in fertility. At a rate of infertile marriages of $15 \%$ and above, its impact on demographics far outweighs the overall impact of miscarriage and perinatal losses. It is difficult to overestimate the social significance of the problem of missing children in marriage. This is the instability of family relationships, the emergence of complex inferiority spouses, 
as well as reducing their social activity. The socio-psychological aspect of this problem is expressed in personal emotional experiences, marital conflicts, extramarital affairs and alcoholism among spouses who are in a barren marriage. The biological side of the problem is that infertility contributes to earlier aging. Women with long-term infertility are more likely to develop malignancies. The medico-genetic aspects of infertility also deserve great attention. An increase in hereditary pathology transmitted from father to mother is not excluded due to the possibility of pathological mutations in the process of examination and treatment of infertile couples. The purely medical relevance of the issue is determined by the need to address a range of tasks related to timely diagnosis and improvement of treatment efficiency, as well as the organization and implementation of infertility prevention. Thus, infertile marriage, because of its practical meaningfulness, is regarded as a medicaldemographic, socio-psychological, biological, medical-genetic and generally medical problem.

For the most effective fight against infertility it is necessary to know the most common causes of this condition. By ethiopathological feature, all cases of female infertility are divided into: tubal occurs as a result of obstruction of the fallopian tubes, endocrine - due to impaired function of the glands of the endocrine system, immunological - as a result of the formation of antisperm antibodies, which interfere with conception, infertility, in which the couple lacks objective reasons for impaired fertility $[1,2,5,9,10]$.

Of greatest clinical interest is endocrine infertility, which results from hypothalamic-pituitaryovarian failure, followed by impaired ovarian function. The cause of infertility in this case may be functional disorders of the reproductive system while maintaining normal anatomical structures of the pelvic organs. Persistent anovulation for a long time, as well as the lack of adequate correction of menstrual dysfunction lead to the development of endocrine-dependent gynecological diseases, manifestation of which is primary or secondary infertility. However, despite numerous studies on the etiologic factors and pathogenetic aspects of endocrine infertility, the lack of comprehensive analysis of the causes of ovarian dysfunction and accurate diagnosis leads to polypragmasia of hormonal drugs and their low efficiency [3].

In addition, idiopathic infertility is a complex and unexplored problem for the time being. This is due, first of all, to the absence in patients with this diagnosis of clear signs of impaired reproductive function, which determines a more in-depth analysis of individual parts of the reproductive system, both functional and morphological $[4,7]$.

So, today, the problem of fertility reduction is quite urgent. At the same time, it should be noted that the effectiveness of infertility treatment, even using the latest techniques, tools and drugs does not exceed $35-40 \%$. This can be explained by insufficient study of a number of causes that lead to impaired fertility.

One of these little-known and unknown factors is the pelvic venous plethora, in particular the varicose veins of the ovaries. While anatomically similar disease in men - varicocele - is of considerable importance, in women even the very fact of the existence of this pathology is controversial among some authors.

The prevalence of pelvic varicose veins of the venous collectors in women is estimated from a single case to $1 / 3$ of patients suffering from infertility. Etiological and pathogenetic moments of functional infertility on the background of pelvic varicose veins, in particular the ovary, according to modern literature has not been sufficiently studied. Increased inflow of venous blood through the ovarian vein is accompanied by phlebostasis and phlebohypertension in the venous sector of the internal genital organs. The thinning of the venous wall due to its stretching causes an increase in the permeability of the intercellular contacts of the endothelium and the appearance of intercellular edema. The increased viscosity and rheological properties of the blood, which take place in this way, lead to impaired transcapillary metabolism and transport of oxygen to the tissues. Reduced oxygen delivery to the ovary is reflected in its functional properties. Reduction of ovarian vascularization is accompanied not only by the cessation of follicle growth and decrease in their growth, but also by the development of degenerative changes in their structures. In the ischemic ovary, degenerative changes in the follicular apparatus, yellow bodies are observed, with subsequent spread to all structural elements of the ovary, which leads to its atrophy and decrease in functional properties. In addition, the increase in circulating blood volume is accompanied by stagnation not only in the ovary but also in the uterus, fallopian tubes. Venous congestion in the tubes causes their swelling, which can lead to narrowing of the lumen of the fallopian tubes and reduce the effectiveness of their function. 
Therefore, all of these factors can form the pathogenetic basis for the occurrence of dysfunction of the genital glands and internal genital organs with the subsequent development of infertility [9].

Thus, impaired venous circulation in the pelvic organs plays a significant role in the structure of gynecological pathology [10].

The aim of our work was to solve the urgent problem of modern gynecology - to improve the reproductive potential of women with infertility on the background of pelvic venous plethora by studying the cause-and-effect relationships and optimizing approaches to its diagnosis and treatment.

\section{Materials and methods.}

All studies were conducted in compliance with the basic bioethical standards and requirements of the Declaration of Helsinki. 117 women of reproductive (21-42 years) age with infertility of functional genesis were examined. During the study were used: questionnaire-anamnestic, clinical, biochemical, bacterioscopic, bacteriological, virological, enzyme immunoassay, high-frequency ultrasonography with pulse Doppler imaging, selective ovarianography, pelvic phlebography.

\section{Results. Discussion.}

According to the results of the analysis, it is established that the clinical-anamnestic features of women with infertility and ovaricaricocele are an increase in the proportion of patients with intellectual differentiation of work and psycho-emotional and physical activity, high frequency of infectious diseases of childhood $-85.5 \%$, diseases of the body by ENT organs $-53.1 \%$, respiratory organs $56.4 \%$, urinary system $-43.5 \%$, and in the structure of gynecological diseases - inflammation of the appendix (45.2\%), vagina and cervix $(24.2 \%)$ from with nocturnal abortion rate $(43.5 \%)$ in pregnancy after 6 weeks (30.6\%), regular menstrual cycle $(77.5 \%)$, normal duration $(43.6 \%)$ with excessive blood loss during menstruation $(54,8 \%)$ and its duration is more than 6 days $(50,1 \%)$ with acyclic uterine bleeding $(37,1 \%)$, dysmenorrhea $(56,4 \%)$ and premenstrual disorders $(51,6 \%)$.

The anatomical and functional state of the pelvic organs and venous system in women with infertility and ovaricaricocele was found to be characterized by a decrease in ovarian volume of $4.1 \pm$ $0.1 \mathrm{~cm} 3$ and the number of antral follicles $3.9 \pm 1.1$ with a tendency to decrease in the gradient age , decrease in the thickness of the endometrium in the middle of the luteal phase $8 \pm 1,4 \mathrm{~mm}$, the absence of its adequate secretory changes (83.8\%) against the background of $100 \%$ increase in the diameter of the ovarian veins of the predominantly "scattered" type $-45,2 \%$, mainly in the left half of the small pelvis $-80.6 \%$.

The hormonal profile of women with infertility and ovaricaricocele was found to be decreased by estradiol $(34.2 \pm 2.4 \mathrm{pg} / \mathrm{ml})$ and progesterone $(5.21 \pm 0.11 \mathrm{ng} / \mathrm{ml})$ during the entire menstrual cycle against the background of increased FSH concentration in the follicular phase of the cycle (10.6 $\pm 0.64 \mathrm{mIU} / \mathrm{ml}$ ) to increase the ratio of $\mathrm{FSH} / \mathrm{LH}$, there is a statistically significant decrease in the antimuler hormone $1.2 \pm 0.3 \mathrm{ng} / \mathrm{ml}$ and inhibin B $29.1 \pm 1.5 \mathrm{PG} / \mathrm{ml}$, which is evidence of insufficiency of the ovarian reserve with a decrease in hormone-producing function of the gonads.

The study found that women with infertility and ovaricaricocele have endothelial dysfunction, which is characterized by increased production of vascular growth factors, indicating the activation of angiogenesis and proliferation, prostaglandin F2 $\alpha(2086,3 \pm 138,7 \mathrm{pg} / \mathrm{ml})$ and prostaglandin E2 $(773.4 \pm 53.8 \mathrm{pg} / \mathrm{ml})$, endothelin- $(4.3 \pm 0.09 \mathrm{pg} / \mathrm{ml})$, which have pro-aggregate and proinflammatory properties, reduced prostacyclin $(183.7 \pm 1.17 \mathrm{pg} / \mathrm{ml}) \mathrm{ml})$ with antiplatelet properties with hypercoagulation in the hemostasis system (reduction of of the tissue plasminogen activator (4.2 $\pm 0.5 \mathrm{ng} / \mathrm{ml})$ and increased synthesis of its inhibitor $(27.57 \pm 1.7 \mathrm{IU} / \mathrm{ml})$ against the background of increasing the concentration of D-dimer in the blood plasma $-0.77 \pm 0,08 \mathrm{mcg} / \mathrm{ml}$ ), with the presence of a direct strong correlation between the markers of endothelial dysfunction and hypoprogesteroneemia, which indicates the ischemization of the ovarian tissue and a decrease in its hormone-producing function.

Women with infertility and ovaricaricocele were found to have a reduced ovarian reserve in $74.4 \%$ of cases, characterized by a shortened menstrual cycle - $29.0 \%$, with acyclic uterine bleeding - $37.1 \%$, statistically significantly increased FSH $12.4 \pm 3,08 \mathrm{mIU} / \mathrm{ml}$, decrease of inhibin B indices $-22,9 \pm 0,14 \mathrm{pg} / \mathrm{ml}$ and antimulyer hormone - $0,76 \pm 0,2 \mathrm{ng} / \mathrm{ml}$ against the background of reduced ovarian volume $-4,7 \pm 0,11 \mathrm{~cm} 3$ and the number of antral follicles $-4,5 \pm 0,02$.

Pathogenetically grounded algorithm for diagnostics and treatment of women with infertility and ovaricaricocele, based on clinical data, results of instrumental methods of examination and presented with a two-stage scheme: first stage - improvement of venous hemodynamics on the 
background of varicose veins and ulcerations conservative therapeutic complex in the form of a combination of needle needles, methyl chalcone gesperdine and ascorbic acid, ultrasound therapy with actovegin gel intravaginally in combination with laparoscopic resection of the ovarian veins in the presence of pathological renal-ovarian reflux; the second stage is the regulation of the levels of the sex hormones - estradiol and progesterone depending on the type of hormonal balance disturbance by the use of dydrogesterone or complex $17 \beta$ of estradiol and dydrogesterone.

It was proved that the efficiency of the developed methods of two-stage treatment of infertility and ovaricaricocele was characterized by improvement of venous hemodynamics of the pelvis due to the acceleration of the velocity in the pelvic venous collectors, namely in the ovaries $7,24 \pm 0,12 \mathrm{~cm} / \mathrm{s}$, uterine $-7,32 \pm 0 \mathrm{~cm} / \mathrm{s} 06 \mathrm{~cm} / \mathrm{s}$ and internal sciatic veins $-7.32 \pm 0.11 \mathrm{~cm} / \mathrm{s}$ with a decrease in clinical manifestations of dyshormonal disorders by 4.5 times, a significant increase in the concentration of estradiol $(57.1 \pm 1.8 \mathrm{pg} / \mathrm{ml})$ and progesterone $(16,29 \pm 0,6 \mathrm{ng} / \mathrm{ml})$, reducing the concentration of FSH in the follicular phase of the cycle $(4,25 \pm 0.1 \mathrm{mMO} / \mathrm{ml})$ with the onset of spontaneous pregnancy in $72.5 \%$ of cases and in 14.5 after the use of ECF techniques.

Thus, the urgent task of modern gynecology is to improve the reproductive potential of women with infertility on the background of pelvic varicose veins by studying the cause-and-effect relationships and optimizing approaches to its diagnosis and treatment.

\section{REFERENCES}

1. Булавенко, О.В., Григоренко, А.Н., \& Сливка, Э.В. (2016). Хирургическая коррекция состояния недостаточности лютеиновой фазы у женщин с варикозным расширением гонадных вен. Сборник трудов конференции, 159-164.

2. Булавенко, О.В. \& Дощечкин, В.В. (2017). Ультрасонографическая оценка овуляторной стигмы и проноз исхода роста доминантного фолликула. Репродуктивна ендокринологія, 4 (36), 36-42.

3. Ночвіна, О.А. (2016). Доплерометричні характеристики мозкового кровообігу у жінок із синдромом хронічного тазового болю. Вісник морфології, 1(22), 134-137.

4. Ночвіна, О.А., \& Жук, С.І. (2014). Синдром хронічного тазового болю в генезі стрес-індукованого безпліддя у жінок репродуктивного віку. 3 турботою про жінку, 2 (50), 181-184.

5. Чечуга,С.Б. \& Силин, Г.А. (2015). Патогенетическое обоснование консервативного лечения овариковарикоцеле у женщин репродуктивного возраста. Репродуктивное здоровье. Восточная Европа, 40 (4), 26-31.

6. Labropoulos, N., Malgor, R.D., Comito, M., Gasparis, A.P. et.al. (2015). The natural history and treatment outcomes of symptomatic ovarian vein thrombosis. J Vasc Surg Venous Lymphat Disord, 3(1), 42-47.

7. Tu, F.F., Hahn, D. \& Steege, J.F. (2010). Pelvic congestion syndrome-associated pelvic pain: a systematic review of diagnosis and management. Obstet Gynecol Surv, 65(5), 332-340.

8. Durham, J.D., Machan, L. (2013). Pelvic congestion syndrome. Semin Intervent Radiol, 30(4), 372-380.

9. Hansrani, V., Dhorat, Z. \& McCollum, C.N. (2016). Diagnosing of pelvic vein incompetence using minimally invasive ultrasound techniques. Vascular, 25(3), 253-259.

10. Labropoulos, N., Jasinski, P.T., Adrahtas, D. et.al. (2016). Standardized ultrasound approach to pelvic congestion syndrome. Phlebology, 32(9), 608-619. 